\title{
ON THE ISSUE OF REGULATORY FRAMEWORK FOR STATE GOVERNANCE AND MANAGEMENT OF ECONOMIC ACTIVITIES IN UKRAINE
}

The aim of this article is to consider the regulatory framework of state governance and management of economic activity in Ukraine the notion of relevant framework, the nature of the relations that such framework applies its effectiveness.

The methods of formal logic are used: analysis, synthesis, induction, deduction, analogy, generalization. The author analyzes the notion of "legislative" and "framework", based on she synthesizes and generalizes her own vision of the concepts of "legislative framework" and "regulatory framework". Relationship about state governance and management of economic activity is delimited deductively. Conclusions are drawn about the effectiveness of the regulatory framework of the relevant direction of State's activities with applying induction.

The view expressed that the legislative framework should be included only laws of Ukraine and international agreements ratified by the Verkhovna Rada of Ukraine, the consent of which is binding on the Verkhovna Rada of Ukraine.

Results and conclusions. It is emphasized on the need to delimit the terms "regulatory framework", "legislative framework", "law framework". The ratio of the latter two concepts can be determined by analogy between the concepts of "system of legislation" and "system of law".

The author draws attention to the fact that the principle of the definition of the range of relations covered by the regulatory framework for state governance and management of economic activity is the understanding of the subject of such activity - the state, which is endowed with both powers of authority and economic legal personality. At first case, it is state governance, at second - state management. Therefore, the relevant regulatory framework unites sources that determine the rules of conduct for the state-the subject of power and the state - a subject with economic legal personality.

It was also emphasized that the quality of the regulatory framework of state governance and management of economic activity in Ukraine depends on the proper implementation of the state regulatory policy in the field of economic activity, primarily the principles of the relevant policy. They defined by the Law of Ukraine "On the Principles of State Regulatory Policy in the Field of Economic Activity": expediency, adequacy, efficiency, balance, predictability and take into account of public opinion.

The latter may serve as criteria for regulatory acts in the field of economic activity, the discrepancy with them is indicates the poor quality of such legal act and the inexpediency of acceptance. At the same time, the quality of regulatory acts indicates the level of state regulatory policy as a whole, and their application effectiveness of state governance of economic activities.

The author made a conclusion that in order to eradicate the practice of adopting regulatory acts on the same issues, relevant legislation should be primarily incorporated with subsequent codification. Those regulatory acts that management economic, in particular, organizational and economic relations, shall be codified within the Economic Code of Ukraine, those acts that govern administrative relations - in a special law and future Code of Administrative Procedures.

Key words: legislation, legislative, economic legal personality of the state, powers of the state, principles of state regulatory policy, systematization of legislation. 


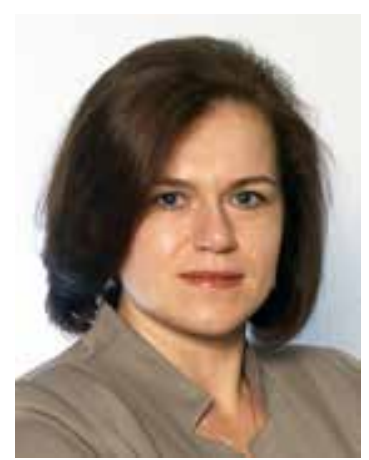

Svitlana Bevz, Associate Professor of the Department of Economic and Administrative Law of the National Technical University of Ukraine "Igor Sikorsky Kyiv Polytechnic Institute", PhD in Law, Associate Professor orcid.org/0000-0003-1331-3930 bevzsvetlana@ukr.net

\section{Introduction}

Development of market relations, active integration processes in which Ukraine is involved, constant legislative changes complicate operation processes of various economic entities, their engagement in various types of economic activities. It is a well-known fact that the proper operation of economic entities of various forms of incorporation and forms of ownership is a guarantee for the development of state economy as a whole. At the same time, the proper economy organization in any state is essential for the successful state activity, satisfaction of citizens' demands, ensuring the social orientation of its development. For the effective operation of any organized system, it requires proper management. An important role in management of such a system as an economy assigned to the state.

In many scientific legal studies we may find the terms "regulatory", "legislative", "law" framework. However, their clear definition was not developed. At the same time, it's commonly believed that such framework is the foundation, the basis for the certain type of activity, which determines its limits, particularly when it comes to the state, its activities and implementation of its functions. This article is devoted to such range of problems.

2. The concepts of "legislative", "regulatory" and "legal" framework

When defining the legislative framework, academics generally indicate it's components instead of giving definition to the concept. I.H. Yanenkova, when analyzing the legislative framework for the operation of enterprises, points out that "it covers both economic laws in its own sense, as well as other regulatory acts governing economic life issues" (Yanenkova, 2012). Legislative framework as a range of regulatory acts (Nahorichna, Konovalov, 2014) or their corpus (Yushyna, 2007) as respective legislation (Bakalinska, 2014) is interpreted also in other studies. When elaborating the new provisions on legal foundations of state regulation of entrepreneurial activity in Ukraine, V.V. Dobrovolska (Dobrovolska, 2007) defines the law framework for state regulation of entrepreneurial activity, pointing out that this concept has no unequivocal definition, being still under development, and analyzes some particular regulations. T.M. Kravtsova in her study states that "laws and regulations ensure the necessary legal regime of provision and protection of public and private interests in the field of economic activity" 
(Kravtsova, 2006), however, she neither propose a definition of provision nor specify the type of provision in question, whether legislative or law.

In order to determine the concept of "legislative framework" it is worth referring to the etymology of the concepts that make up this phrase.

The concept of "provision", in particular, means "satisfaction of someone, something in any needs, creating of reliable conditions for the implementation of something, ensuring something" (Slovopediia; Busel, 2005). Therefore, legislative provision can be understood as creating reliable conditions for the implementation of something, ensuring something at the legislative level.

The term "legislative" derives from the noun "legislation", the definition of which enables us to understand what the concept of "legislative" implies.

As it comes from the literature, the notion of "legislation" is possible to apply both in broad and narrow sense. Broad approach means that the notion of legislation covers the acts of legislative bodies and subordinate acts (acts of state administration agencies, etc.). The narrow approach includes the acts of the legislative body and resolutions of the Verkhovna Rada enacting these laws (Skakun, 2000). This position is debatable.

Throughout the textbooks you may also find a view that a broad understanding of legislation undermines the role of law, combining laws and subordinate acts. The broad understanding of legislation is the way to attenuate the law, to substitute it with managerial decisions (Livshits, 1994). Interesting is the position of the Constitutional Court of Ukraine set out in the decision № 12-pn/98 of July 9, 1998 as for the term of "legislation" (Constitutional Court of Ukraine, 1998). According to this decision of the Constitutional Court, the concept of "legislation" covers the laws of Ukraine, international treaties Ukraine in force declared binding by the Verkhovna Rada of Ukraine as well as resolutions of the Verkhovna Rada of Ukraine, decrees of the President of Ukraine, decrees and resolutions of the Cabinet of Ministers of Ukraine approved within their competence and authorities and pursuant to the Constitution of Ukraine and the laws of Ukraine. Thus, the concept of "legislation" does not cover regulatory acts issued by central executive authorities. That is, in our opinion, not sufficiently justified, since the acts of the highest body of executive power are covered by this concept. However, proceeding from the approach of the theory of administrative law which does not lodge the state administration with the powers to adopt subordinate legal acts, empowering it to concentrate its efforts on executive activities related to application of laws and issue of individual administrative acts of personified nature exclusively (Halunko et al., 2018) it can be argued that such a position of the Constitutional Court actually supports this approach. At the same time, we consider the practical implementation of such an approach in our state to be impossible at its present development stage.

At the same time the judgment of the Constitutional Court of Ukraine on the constitutional application of the Supreme Court of Ukraine on compliance with the Constitution of Ukraine (constitutionality) of the provisions of Article 69 of the Criminal Code of Ukraine (the case on imposition of reduced sentence) (Constitutional Court of Ukraine, 2004) states that one of the instances of the rule of law is that the law is not limited to legislation as one of its forms only. It also includes other social controllers as well, in particular norms of morality, traditions, customs, etc., legitimated by society 
and determined by historically achieved cultural level of society. Therefore, legislation is not the only form of law, thus this concept should not cover the whole range of regulatory controllers existing in society.

Approaches to interpretation of "legislation" concept are integrated into the legal encyclopedia (Shemshuchenko, 1999). It gives several definitions of the concept: 1) the system of laws of Ukraine; 2) in the broad sense, the system of laws and other regulatory acts adopted by the Verkhovna Rada of Ukraine and the highest bodies of executive power - resolutions of the Verkhovna Rada, decrees of the President of Ukraine, resolutions and decrees of the Cabinet of Ministers of Ukraine; 3) in the broadest sense, a system of laws and resolutions of the Verkhovna Rada of Ukraine, decrees of the President of Ukraine, resolutions, decrees and ordinances of the Cabinet of Ministers of Ukraine, as well as regulatory acts of departments and agencies, local councils and local state administrations.

It stands to mention the separate opinion of M.D. Savenko as to the decision of the Constitutional Court of Ukraine of July 9, 1998 № 12-pп/98, in which he stated that the concept of "legislation" should be restricted to a set of laws adopted by the Verkhovna Rada of Ukraine (Savenko, 1998).

Such interpretation of this term will promote a unified approach to its essence, the certainty of the range of subjects authorized to regulate particular social relations by adopting relevant legislation. After all, pursuant to the Constitution of Ukraine (Article 75), the only body of legislative power in Ukraine is the Parliament - Verkhovna Rada of Ukraine, which adopts laws and declares binding international treaties in force. Thus, legislative framework should be represented only by the laws of Ukraine and international treaties ratified by the Verkhovna Rada of Ukraine, which declared them binding (Verkhovna Rada of Ukraine, 1996).

Therefore, it is required to make a distinction between the terms "regulatory framework" and "legislative framework". At the same time, the latter is a component of the first.

We should also point out that it makes sense to consider also the relationship between the above concepts with the concept of "law framework" when defining the framework for state governance and management of economic activities.

In our opinion, it is possible to determine the interrelation of these concepts by analogy between the concepts of "system of law" and "system of legislation". Ye.V. Petrov aptly pointed out that "the system of law and the system of legislation may coexist in a large number of variations, from complete discrepancy to complete substitution of the system of law by the system of legislation. Both options are typical for the states with undemocratic regime of state power organization and implementation. Existence of law and legislation side-by-side, as well as negation of law beyond the scope of legislation is typical for such regimes. In democratic states, the system of legislation is an integral part of the system of law" (Petrov, 2012). Consequently, legislative framework is one of the elements of regulatory framework - shall be an integral part of law framework.

Then, the regulatory framework for state governance and management of economic activities is represented by the sources of legal regulation of state's implementation of such activities. Identification of such sources for state governance and management of economic activities determines the need to make a distinction between the relations that may arise in such a case. 


\section{The essence of state management of economic activities}

State governance and management of economic activities is performed primarily by the relevant state authorities that exercise their powers within the limits prescribed by the Constitution and subject to compliance with the laws of Ukraine.

In determination of the range of relations covered by the regulatory framework for state governance or management of economic activities, the principal is the issue of understanding the subject of such activity - the state, which possess both powers of authority and economic legal personality.

Implementation of relevant activity by the state as a power entity should understood as state governance of economic activities. It involves the organizational and power activities of state authorities (officials), which implements the functions of state governance of the social relations that originate, change and terminate resulting from engagement in economic activities or implementation of the intention to engage in them by state at large and aimed at performing the economic function of the state.

In the case when the state implements its economic legal personality (state management of economic activities), it exercises state administration in relation to enterprises created on its own or through its participation by means of organization and management of the economic activities of a particular enterprise.

Thus, the essence of the concept of "state governance of economic activities" should base on the concept of state regulation of the economy, since the concept of "economy" means state economy as a whole. While the state management of economic activities actually means organizational and economic relations, in which the government authority acts as a subject of organizational and economic powers, realizing its economic legal personality. Organizational and economic relations that mediate the state management of economic activity at the micro level have their own peculiarities related to the legal regime of property used to establish a business entity, which determines the specifics of state corporate rights.

Due to aforementioned, the regulatory framework for state governance and management of economic activities integrates sources that determine the rules of conduct for a state as a subject of power and a state as a subject with economic legal personality.

It is worth noting that during the Ukraine's membership within the USSR and purely state ownership of the national economy, the issue of regulatory framework for relevant activities of state was by definition treated in a comprehensive way. In this case, it was a question of state regulation of the national economy. After all, each economic entity was in charge of a certain state authority, and "in reality, the management body and its subordinate entities worked in a strong connection, close unity, their activities were a seamless whole - the process of economic activity in a certain part of the socialist economy" (Pronska, 2013). It was not necessary to separate state governance and state management.

\section{The issues of effectiveness and improvement of regulatory framework}

Effectiveness of regulatory framework for state governance and management of economic activities depends to a large extent on law enforcement practice. Unlike many other states, Ukraine has quite high level of regulatory activity development, however law enforcement practice is still deficient and ineffective (Bakalinska, 2014). As it fol- 
lows from the periodicals, "when it comes to the legal support of economy, the loss of the connection between science and legislative practice is worth attention. It needs to be recognized that parliamentary practice, which may be characterized by progressive clannishness and utilitarian approach has technically turned away from science, however science does not display perseverance in advocating its positions as for improving the quality of legislation" (Znamenskyi, 2010). At the same time, law-making even actualized in the form of unsystematic development of economic and legal legislative innovations may confirm or refute many findings of the science of economic law. After all, law-making objectively tends to the actual needs of social interactions, and has certain objective regularities indicating the directions for further economic and legal development (Podtserkovnyi, 2010).Therefore, only choosing one object (for the purpose of study and formulation of proposals - by researcher, for regulation of state relations involving this object - by lawmakers) may show discrepancy or similarity between the views of scientists and lawmakers, but, unfortunately, not their cooperation aimed at creation of effective legal regulation.

Thus, success in development of laws and subordinate regulatory acts is of a direct dependence of rule maker's legal culture, their level of proficiency in rulemaking technique, depth of scientific support, and due consideration of public opinion in this process.

The scholars believe that legal technology will become a panacea for high quality legislation. The legal technique is aimed at the perfect formation of a regulatory act and its contents. It should ensure a high quality of both legislative and subordinate act, that is, its compliance with all content-related criteria and formal legal requirements (Lehin, 2016).

We believe that the quality of regulatory framework for state governance of economic activity depends basically on the proper implementation of the state regulatory policy in the field of economic activity, principles of such policy stipulated by Law of Ukraine "On Principles of State Regulatory Policy in Economic Activity": advisability, adequacy, efficiency, balance, predictability and due regard to state opinion. These principles may serve as criteria for regulatory acts in the field of economic activity, and inconsistency with them indicates the poor quality of particular legal act and inadvisability of its adoption. At the same time, the quality of regulatory acts clearly shows the level of state regulatory policy on the whole, while their application - the effectiveness of state governance of economic activities.

The need to improve the regulatory framework for state governance and management of economic activities, get rid of obsolete norms, eliminate the gaps in current regulatory acts, harmonization for the effective application of legislative acts determines the advisability to systematize legislation in the area in question. We share the opinion of V.P. Plavych that "harmonization of legislation on the principles established by the Constitution, overcoming the conflicts between the Constitution and laws, as well as harmonization of the provisions of national legislation with international law is possible in the most effective way through the systematization of legislation" (Plavych, 2002). Branch division, complexity and diversity of regulating acts constituting the regulatory framework of state governance and management of economic activities do not provide 
an opportunity to choose a certain type of its systematization. Therefore, we believe that in order to eradicate the practice of adopting regulatory acts on the same issues, relevant legislation should be primarily incorporated with subsequent codification.

Taking into account the fact that the regulatory framework for state governance and management of economic activities includes regulatory acts of administrative and economic law, which once again justifies the importance of differentiation of relations that arise during state's performance of this activity, they should have different basis for incorporation and codification.

Those regulatory acts that management economic, in particular, organizational and economic relations, shall be codified within the Economic Code of Ukraine, which is open to regulate the procedure on implementation of organizational and economic powers, especially in the state sector of the economy. Those acts that govern administrative relations shall be codified within the framework of the development and adoption of a special law. It would determine the basis for interaction between state authorities, local self-government and private individuals which pursues establishing the economic order in Ukraine, as well as the future Code of Administrative Procedures (Administrative Procedural Code) in a separate section on the procedural issues of such interaction.

Therefore, the main purpose of such systematization is establishing clear and effective regulatory framework for state governance and management of economy aimed at achieving priorities specified in the Strategies and Concepts of our State's Development approved by the Verkhovna Rada of Ukraine and the Cabinet of Ministers of Ukraine. As it follows from the scientific works, the world practice has far back proven that legislation can be considered civilized only when it represents a systemic balance of expediency, justice and stability (Znamenskyi, 2010). That is the conditions which can be achieved in compliance with the principles of state regulatory policy in the field of economic activity that allow us to claim that the regulatory framework of state governance and management of economic activities in Ukraine is of high quality and efficiency.

\section{Conclusions}

Thus, the regulatory framework of state governance and management of economic activity is one of the constituent elements of law framework and includes legislative framework, but not limited to the latter. The ratio of the "legislative framework" and "law framework" can be determined by analogy between the concepts of "system of legislation" and "system of law". To determine the sources of regulatory framework of state governance and management of economic activity, it is necessary to take into account two levels of state activity in economic sphere - macro level (the state implements powerstate governance) and micro level (the state implements economic competence - state management). Therefore, the relevant regulatory framework unites sources that determine the rules of conduct for the state - the subject of power and the state - a subject with economic legal personality.

Quality of the regulatory framework of state governance and management of economic activity in Ukraine depends on the proper implementation of the state regulatory policy in the field of economic activity, primarily the principles of the relevant policy. They defined by the Law of Ukraine "On the Principles of State Regulatory Policy in the Field of Economic Activity": expediency, adequacy, efficiency, balance, predictabil- 
ity and take into account of public opinion. The latter may serve as criteria for regulatory acts in the field of economic activity, the discrepancy with them is indicates the poor quality of such legal act and the inexpediency of acceptance. At the same time, the quality of regulatory acts indicates the level of state regulatory policy as a whole, and their application effectiveness of state governance of economic activities.

The dispersion of the relevant norms, the variety of normative legal acts predetermines the need for systematization of the relevant acts, which will have an impact on the effectiveness of their application. Proper implementation of the state regulatory policy in the field of economic activity, adherence to the principles of the relevant policy should also contribute to improving the efficiency of the regulatory framework for state governance and management of economic activities.

\section{Bibliography:}

1. Яненкова І.Г. Законодавче забезпечення діяльності підприємств. Наукові праиі Чорноморського державного університету імені Петра Могили. Серія «Економіка». Миколаїв : Вид-во ЧДУ ім. Петра Могили, 2012. Т. 189. Вип. 177. С. 81-86.

2. Нагорічна О.С., Коновалов Ю.О. Законодавче забезпечення процесу державного регулювання наукової діяльності. Державне управління: удосконалення та розвиток. 2014. № 5. URL: http://www.dy.nayka.com.ua/?op=1\&z=724 (дата звернення: 11.05.2019).

3. Юшина С.I. Державне регулювання зовнішньої торгівлі в Україні : монографія. Київ : КНТЕУ, 2007. 149 с.

4. Бакалінська О.О. Правове регулювання добросовісної конкуренції в Україні : монографія. Київ : НДІ приватного права і підприємництва імені академіка Ф.Г. Бурчака НАПрН України, 2014. 373 с.

5. Добровольська В.В. Правові засади державного регулювання підприємницької діяльності в Україні : дис. ... канд. юрид. наук. Одеса, 2007. 225 с.

6. Кравцова Т.М. Державне регулювання господарської діяльності: адміністративноправові аспекти : монографія. Суми : ВВП «Мрія» ТОВ, 2006. $184 \mathrm{c}$.

7. Забезпечення, забезпеченість. Словопедія. URL: http://slovopedia.org.ua/32/53399/ 30821.html (дата звернення: 11.05.2019).

8. Великий тлумачний словник сучасної української мови / уклад. і гол. ред. В.Т. Бусел. Київ ; Ірпінь : ВТФ «Перун», 2005. 1728 с.

9. Скакун О.Ф. Теория государства и права : учебник. Харьков : Консум ; Университет внутренних дел, 2000. $704 \mathrm{c}$.

10. Лившиц Р.3. Теория права : учебник. Москва : БЕК, 1994. 224 с.

11. Рішення Конституційного Суду України у справі за конституційним зверненням Київської міської ради професійних спілок щодо офіційного тлумачення частини третьої статті 21 Кодексу законів про працю України (справа про тлумачення терміну «законодавство») від 9 липня 1998 р. № 12-рп/98 / Конституційний Суд України. Офіџійний вісник України. 1998. № 32. С. 59. Ст. 1209.

12. Адміністративне право України. Повний курс : підручник / В.В. Галунько, П.В. Діхтієвський, О.В. Кузьменко, С.Г. Стеценко та ін. Херсон : ОЛДІ-ПЛЮС, 2018. 446 с.

13. Рішення Конституційного Суду України у справі за конституційним поданням Верховного Суду України щодо відповідності Конституції України (конституційності) положень статті 69 Кримінального кодексу України (справа про призначення судом більш м'якого покарання) від 2 листопада 2004 р. № 15-рп/2004 / Конституційний Суд України. Офіційний вісник України. 2004. № 45. С. 41. Ст. 2975. 


\section{ОСОБЛИВЕ АДМІНІСТРАТИВНЕ ПРАВО}

14. Юридична енциклопедія : в 6 т. / за ред. Ю.С. Шемшученка. Київ : «Українська енциклопедія» ім. М.П. Бажана, 1999. Т. 2 : Д - Й. 744 с.

15. Окрема думка судді Савенка М.Д. стосовно рішення Конституційного Суду України від 9 липня 1998 р. № 12-pп/1998. URL: http://www.ccu.gov.ua/docs/391 (дата звернення: 11.05.2019).

16. Конституція України : Закон України від 28 червня 1996 р. № 254к/96-ВР (станом на 1 травня 2019 р.) / Верховна Рада України. URL: https://zakon.rada.gov.ua/laws/ show/254к/96-вр (дата звернення: 11.05.2019).

17. Петров Є.В. Адміністративно-господарське право як підгалузь адміністративного права України : дис. ... докт. юрид. наук. Харків, 2012. 417 с.

18. Пронська Г.В. Правова організація галузевих господарських систем (на прикладі Української РСР). Пронська Г.В. Вибране. Київ : Освіта України, 2013. С. 133-263.

19. Знаменський Г.Л. Наукоємність сучасного господарського права. Право України. 2010. № 8. С. 19-25.

20. Подцерковний О.П. Про перевірку висновків науки господарського права тенденціями розвитку господарського законодавства. Право України. 2010. № 8. С. 39-46.

21. Легін Л.М. Поняття і критерії якості закону: проблеми визначення. Проблеми законності. 2016. № 132. С. 196-204.

22. Плавич В.П. Правове регулювання трансформаційної економіки України і розвиток національного законодавства. Київ : Інститут держави і права ім. В.М. Корецького НАН України, 2002. 141 с.

\section{References:}

1. Yanenkova, I.H. (2012). Zakonodavche zabezpechennia diialnosti pidpryiemstv [Legislative support of the activity of enterprises]. Naukovi pratsi Chornomorskoho derzhavnoho universytetu imeni Petra Mohyly. Seriia "Ekonomika". Mykolaiv: Vyd-vo ChDU im. Petra Mohyly, vol. 189, issue 177, pp. 81-86 [in Ukrainian].

2. Nahorichna, O.S., Konovalov, Yu.O. (2014). Zakonodavche zabezpechennia protsesu derzhavnoho rehuliuvannia naukovoi diialnosti [Legislative framework of the process of state regulation of scientific activity]. Derzhavne upravlinnia: udoskonalennia ta rozvytok, no. 5. Retrieved from: http://www.dy.nayka.com.ua/?op=1\&z=724 [in Ukrainian].

3. Yushyna, S.I. (2007). Derzhavne rehuliuvannia zovnishnoi torhivli v Ukraini: monohrafiia [State regulation of foreign trade in Ukraine: monograph]. Kyiv: KNTEU [in Ukrainian].

4. Bakalinska, O.O. (2014). Pravove rehuliuvannia dobrosovisnoi konkurentsii v Ukraini: monohrafiia [Legal regulation of fair competition in Ukraine: monograph]. Kyiv: NDI pryvatnoho prava i pidpryiemnytstva imeni akademika F.H. Burchaka NAPrN Ukrainy [in Ukrainian].

5. Dobrovolska, V.V. (2007). Pravovi zasady derzhavnoho rehuliuvannia pidpryiemnytskoi diialnosti v Ukraini [Legal basis of state regulation of business activity in Ukraine] (Candidate's thesis). Odesa [in Ukrainian].

6. Kravtsova, T.M. (2006). Derzhavne rehuliuvannia hospodarskoi diialnosti: administratyvno-pravovi aspekty: monohrafiia [State regulation of economic activity: administrative and legal aspects: monograph]. Sumy: VVP "Mriia” TOV [in Ukrainian].

7. Zabezpechennia, zabezpechenist [Software, security]. Slovopediia. Retrieved from: http://slovopedia.org.ua/32/53399/30821.html [in Ukrainian].

8. Busel, V.T. (ed.) (2005). Velykyi tlumachnyi slovnyk suchasnoi ukrainskoi movy [Great explanatory dictionary of modern Ukrainian language]. Kyiv; Irpin: VTF "Perun" [in Ukrainian]. 
9. Skakun, O.F. (2000). Teoriia gosudarstva i prava: uchebnik [Theory of state and law: textbook]. Kharkov: Konsum; Universitet vnutrennikh del [in Russian].

10. Livshits, R.Z. (1994). Teoriia prava: uchebnik [Theory of law]. Moscow: BEK [in Russian].

11. Constitutional Court of Ukraine (1998). Rishennia Konstytutsiinoho Sudu Ukrainy u spravi za konstytutsiinym zvernenniam Kyivskoi miskoi rady profesiinykh spilok shchodo ofitsiinoho tlumachennia chastyny tretoi statti 21 Kodeksu zakoniv pro pratsiu Ukrainy (sprava pro tlumachennia terminu “zakonodavstvo") vid 9 lypnia 1998 r. № 12-pп/98 [Judgment of the Constitutional Court of Ukraine in the case of the constitutional appeal of the Kyiv City Council of trade unions on the official interpretation of part 3 of article 21 of the Labor Code of Ukraine (case on the interpretation of the term "legislation”) of July 9, 1998 № 12-pп/98]. Ofitsiinyi visnyk Ukrainy, no. 32, pp. 59, art. 1209 [in Ukrainian].

12. Halunko, V.V., Dikhtiievskyi, P.V., Kuzmenko, O.V., Stetsenko, S.H. et al. (2018). Administratyvne pravo Ukrainy. Povnyi kurs: pidruchnyk [Administrative law of Ukraine. Full course: tutorial]. Kherson: OLDI-PLIuS [in Ukrainian].

13. Constitutional Court of Ukraine (2004). Rishennia Konstytutsiinoho Sudu Ukrainy u spravi za konstytutsiinym podanniam Verkhovnoho Sudu Ukrainy shchodo vidpovidnosti Konstytutsii Ukrainy (konstytutsiinosti) polozhen statti 69 Kryminalnoho kodeksu Ukrainy (sprava pro pryznachennia sudom bilsh m’iakoho pokarannia) vid 2 lystopada 2004 r. № 15-pп/2004 [Judgment of the Constitutional Court of Ukraine in the case on the constitutional submission of the Supreme Court of Ukraine on the conformity of the Constitution of Ukraine (constitutionality) with the provisions of Article 69 of the Criminal Code of Ukraine (case of imposition by the court of a milder sentence) of 2 November 2004 № 15-pп/2004]. Ofitsiinyi visnyk Ukrainy, no. 45, pp. 41, art. 2975 [in Ukrainian].

14. Shemshuchenko, Yu.S. (ed.) (1999). Yurydychna entsyklopediia: $v 6$ tomakh [Legal encyclopedia: in 6 volumes]. Kyiv: "Ukrainska entsyklopediia" im. M.P. Bazhana, vol. 2: D - Y [in Ukrainian].

15. Savenko, M.D. (1998). Okrema dumka suddi stosovno rishennia Konstytutsiinoho Sudu Ukrainy vid 9 lypnia 1998 r. № 12-pп/1998 [Separate Opinion of the Judge on the Judgment of the Constitutional Court of Ukraine of July 9, 1998 № 12-pп/1998]. Retrieved from: http://www. ccu.gov.ua/docs/391 [in Ukrainian].

16. Verkhovna Rada of Ukraine (1996). Konstytutsiia Ukrainy: Zakon Ukrainy vid 28 chervnia 1996 r. № 254к/96-BP (stanom na 1 travnia 2019 r.) [Constitution of Ukraine: Law of Ukraine of June 28, 1996 № 254к/96-BP (as of May 1, 2019)]. Retrieved from: https://zakon.rada.gov.ua/ laws/show/254к/96-вp [in Ukrainian].

17. Petrov, Ye.V. (2012). Administratyvno-hospodarske pravo yak pidhaluz administratyvnoho prava Ukrainy [Administrative and economic law as a subdivision of administrative law of Ukraine] (Doctor's thesis). Kharkiv [in Ukrainian].

18. Pronska, H.V. (2013). Pravova orhanizatsiia haluzevykh hospodarskykh system (na prykladi Ukrainskoi RSR) [Legal organization of sectoral economic systems (on the example of the Ukrainian SSR)]. Pronska H.V. Vybrane. Kyiv: Osvita Ukrainy, pp. 133-263 [in Ukrainian].

19. Znamenskyi, H.L. (2010). Naukoiemnist suchasnoho hospodarskoho prava [Knowledge of modern economic law]. Pravo Ukrainy, no. 8, pp. 19-25 [in Ukrainian].

20. Podtserkovnyi, O.P. (2010). Pro perevirku vysnovkiv nauky hospodarskoho prava tendentsiiamy rozvytku hospodarskoho zakonodavstva [On the examination of the conclusions of the science of economic law trends in the development of economic legislation]. Pravo Ukrainy, no. 8, pp. 39-46 [in Ukrainian]. 


\title{
ОСОБЛИВЕ АДМІНІСТРАТИВНЕ ПРАВО
}

21. Lehin, L.M. (2016). Poniattia i kryterii yakosti zakonu: problemy vyznachennia [Concept and criteria of law quality: problems of definition]. Problemy zakonnosti, no. 132, pp. 196-204 [in Ukrainian].

22. Plavych, V.P. (2002). Pravove rehuliuvannia transformatsiinoi ekonomiky Ukrainy i rozvytok natsionalnoho zakonodavstva [Legal regulation of the transformational economy of Ukraine and the development of national legislation]. Kyiv: Instytut derzhavy i prava im. V.M. Koretskoho NAN Ukrainy [in Ukrainian].

\section{ДО ПИТАННЯ НОРМАТИВНО-ПРАВОВОГО ЗАБЕЗПЕЧЕННЯ ДЕРЖАВНОГО УПРАВЛІННЯ ГОСПОДАРСЬКОЮ ДІЯЛЬНІСТЮ В УКРАЇНІ}

\author{
Світлана Бевз, \\ доцент кафедри господарського та адміністративного права \\ Національного технічного університету України \\ «Київський політехнічний інститут імені Ігоря Сікорського», \\ кандидат юридичних наук, доцент \\ orcid.org/0000-0003-1331-3930 \\ bevzsvetlana@ukr.net
}

\begin{abstract}
Мета статті - розглянути питання нормативно-правового забезпечення державного управління господарською діяльністю в Україні, а саме поняття відповідного забезпечення, сутність відносин, яких стосується це забезпечення, $і$ його ефективність.

Використовуються методи формальної логіки (аналіз, синтез, індукиія, дедукиія, аналогія, узагальнення). Для визначення поняття «законодавче забезпечення» автор аналізує поняття «законодавчий» та «забезпечення», на підставі чого синтезує й узагальнюе власне розуміння термінів «законодавче забезпечення» та «нормативно-правове забезпечення». Дедуктивним иляхом розмежовуються відносини щзодо державного управління господарською діяльністю. 3 використанням індукції формулюються висновки щзодо ефективності нормативно-правового забезпечення відповідного напряму діяльності держави. Висловлюється позииія, згідно з якою законодавче забезпечення має бути представлене лише законами України та міжнародними договорами, ратифікованими Верховною Радою Украйни, згоду на обов язковість яких надано Верховною Радою Украйни. Результати та висновки. Наголошується на необхідості розмежування термінів «нормативно-правове забезпечення», «законодавче забезпечення» та «правове забезпечення». Співвідношення останніх двох понять може бути визначене за аналогією до співвідношення термінів «система права» й «система законодавства».

Автор звертає увагу на те, щзо принциповим у питанні визначення кола відносин, які охоплюються нормативно-правовим забезпеченням державного управління господарською діяльністю, є розуміння суб'єкта такого управління - держави, яка наділена як владними повноваженнями, так і господарською правосуб'єктністю. Тому відповідне нормативноправове забезпечення об'єднує джерела, що визначають правила поведінки для держави суб' єкта владних повноважень та держави-суб' єкта згосподарською правосуб 'єктністю. Також наголошено на тому, шчо якість нормативно-правового забезпечення державного управління господарською діяльністю в Україні залежить від належної реалізації державної регуляторної політики у сфері господарської діяльності, насамперед визначених Законом України «Про засади державної регуляторної політики у сфері господарської діяльності» принципів відповідної політики: доичільності, адекватності, ефективності,
\end{abstract}


збалансованості, передбачуваності та врахування громадської думки. Останні можуть бути критеріями для регуляторних актів у сфері господарювання, невідповідність яким свідчить про низьку якість певного нормативно-правового акта та недоцільність його прийняття. Водночас якість регуляторних актів свідчить про рівень державної регуляторної політики загалом, а їх застосування - про ефективність державного управління господарською діяльністю. У статті стверджується, щио з метою усунення практики прийняття нормативних актів з одних і тих же питань необхідно насамперед інкорпорувати відповідне законодавство, а потім кодифікувати його: нормативно-правові акти, щзо регулюють організаційно-господарські відносини, - у межах Господарського кодексу Украӥни, а акти, щцо регулюють адміністративні відносини, - у межах спеціального закону та майбутнього Кодексу адміністративних проиедур.

Ключові слова: законодавство, законодавчий, господарська правосуб'єктність держави, владні повноваження держави, принципи державної регуляторної політики, систематизація законодавства. 